\title{
As funções da boa-fé e a construção de deveres de conduta nas relações privadas
}

\section{The roles of good faith and the formation conduct obligations in private relations}

\author{
Marcos Augusto Albuquerque Ehrhardt Junior*
}

\section{Resumo}

O texto analisa o tratamento conferido à boa-fé na experiência jurídica brasileira, com ênfase na boa-fé objetiva e em suas funções integrativa, de criação de novos deveres e de vedação ao exercício disfuncional de um direito, buscandose apresentar os contornos da denominada Teoria dos Atos Próprios em seus diferentes matizes, a saber: venire contra factum proprium, supressio, Surrectio e tu quoque. Pretende-se colaborar com a tarefa do juiz, sempre instado a aferir quais os comportamentos são consentâneos com a boa-fé diante da expansão dos deveres gerais de conduta e sua crescente complexidade.

Palavras-chave: Boa-fé. Deveres gerais de conduta. Venire contra factum proprium.

\section{Abstract}

This paper analyzes the treatment given to good faith legal experience in Brazil, with emphasis on good faith objective and integrative functions, creation of new duties and seal the exercise of a dysfunctional right seeking to present the contours of the so called Theory of Equity Act in its different shades, namely venire contra factum proprium, supressio, Surrectio and tu quoque. It is intended to cooperate with the task of the judge, when asked to assess what behaviors

Doutor em Direito pela Universidade Federal de Pernambuco (UFPE) e mestre pela Universidade Federal de Alagoas (UFAL). Professor de Direito Civil da UFAL, do Centro Universitário CESMAC e da Escola Superior da Advocacia em Alagoas (ESA/AL). Coordenador da Revista Fórum de Direito Civil (RFDC), membro do IBDCIVIL e do Grupo de Pesquisa Constitucionalização das Relações Privadas (CONREP/UFPE). Maceió - AL - Brasil. E-mail: marcosehrhardtjr@uol.com. br 
are consistent with good faith, due to the expansion of the general duties of conduct and its growing complexity.

Keywords: Good faith. Generalduties of conduct. Venire contra factum proprium.

\section{Introdução}

É fácil perceber que a boa-fé está relacionada aos fatores socioculturais de um determinado lugar e momento, refletindo a realidade que informa a ordem jurídica na qual está inserida. No entanto, tal constatação dificulta sua análise e, sobretudo, a comparação de sua utilização nos diversos ordenamentos jurídicos ${ }^{1}$.

Comte-Sponville (1999) denominou de "boa-fé" a palavra para designar, entre todas as virtudes, nossas relações com a verdade. Tratando da questão em um âmbito puramente subjetivo, sustenta que a boa-fé seria "um fato, que é psicológico, e uma virtude, que é moral". Enquanto fato, considera-a como "conformidade dos atos e das palavras com a vida interior, ou desta consigo mesma"; enquanto virtude, relaciona-a com o "amor ou o respeito à verdade"2.

Se se analisar a experiência italiana, ver-se-á que a boa-fé é tratada em diversos dispositivos legais ao longo do Código, merecendo destaque o disposto nos arts. 1.375 ("Il contratto deve essere eseguito secondo buona fede), art. 1.366 ("Il contratto deve essere interpretato secondo buona fede"), sobretudo no art. 1.358, assim redigido: "Colui che si è obbligato o che ha alienato un diritto sotto condizione sospensiva, ovvero lo ha acquistato sotto condizione risolutiva, deve, in pendenza della condizione, comportarsi secondo buona fede per conservare integre le ragioni dell'altra parte $(1175,1375)$ ". No sistema francês, o tema vem disciplinado no capítulo relativo aos efeitos das obrigações, especificamente no art. 1.134: "Les conventions légalement formées tiennent lieu de loi à ceux qui les ont faites. Elles ne peuvent être révoquées que de leur consentement mutuel, ou pour les causes que la loi autorise. Elles doivent être exécutées de bonne foi". O Código de Quebec trata da boa-fé em seu art. $6^{\circ}$ ("Toute personne est tenue d'exercer ses droits civils selon les exigences de la bonne foi") e art. $7^{\circ}$ ("Aucun droit ne peut être exercé en vue de nuire à autrui ou d'une manière excessive et déraisonnable, allant ainsi à l'encontre des exigences de la bonne foi").

2 O autor prossegue afirmando que "não, claro, que a boa-fé valha como certeza, nem mesmo como verdade (ela exclui a mentira, não o erro), mas que o homem de boa-fé tanto diz o que acredita, mesmo que esteja enganado, como acredita no que diz. É por isso que a boa-fé é uma fé, no duplo sentido do termo, isto é, uma crença ao mesmo tempo em que uma fidelidade. É 
Segundo Pablo Stolze Gagliano e Rodolfo Pamplona Filho (2005, p. 72), a boa-fé pode ser entendida como "uma diretriz principiológica de fundo ético e espectro eficacial jurídico. Vale dizer, a boa-fé se traduz em um princípio de substrato moral, que ganhou contornos e matiz de natureza jurídica cogente"

Já se tornou lugar-comum distinguir a forma objetiva da boa-fé de sua tradicional versão subjetiva. Pode-se definir a boa-fé objetiva (Treu und Glauben) como um modelo ético de comportamento que se exige de todos os integrantes da relação obrigacional, em contraposição com a noção subjetiva de boa-fé (Guten Glauben), que significa o estado de crença de um sujeito de estar agindo em conformidade com as normas do ordenamento.

Desse modo, a boa-fé subjetiva ("boa-fé crença") relaciona-se ao desconhecimento de determinada circunstância, no que difere da boafé em sua dimensão normativa, a boa-fé objetiva, que diz respeito à confiança e à legítima expectativa do sujeito ("boa-fé lealdade"). Júnior $(2004)^{3}$ aponta a boa-fé subjetiva como qualidade do sujeito, relativa ao

crença fiel, e fidelidade no que se crê. Pelo menos enquanto se crê que seja verdade. Vimos, a propósito da fidelidade, que ela devia ser fiel antes de tudo ao verdadeiro: isso define muito bem a boa-fé. Ser de boa-fé não é sempre dizer a verdade, pois podemos nos enganar, mas é pelo menos dizer a verdade sobre o que cremos, e essa verdade, ainda que a crença seja falsa, nem por isso seria menos verdadeira. É o que se chama também de sinceridade (ou veracidade, ou franqueza), e o contrário da mentira, da hipocrisia, da duplicidade, em suma, de todas as formas, privadas ou públicas, da má-fé. [...] A boa-fé é uma sinceridade ao mesmo tempo transitiva e reflexiva. Ela rege, ou deveria reger, nossas relações tanto com outrem como conosco mesmos. Ela quer, entre os homens como dentro de cada um deles, o máximo de verdade possível, de autenticidade possível, e o mínimo, em consequência, de artifícios ou dissimulações. Não há sinceridade absoluta, mas tampouco há amor ou justiça absolutos: isso não nos impede de tender a elas, de nos esforçar para alcançá-las, de às vezes nos aproximarmos delas um pouco... A boafé é esse esforço, e esse esforço já é uma virtude" (COMTE-SPONVILLE, 1999, p. 106-7).

3 Nesse sentido, dispõe o art. 1.201 do CC/02: "É de boa-fé a posse, se o possuidor ignora o vício, ou o obstáculo que impede a aquisição da coisa". Como consequência, o possuidor de boa-fé tem direito, enquanto ela durar, aos frutos percebidos (art. 1.214), além de não responder pela perda ou deterioração da coisa, a que não der causa (art. 1.217). Outros exemplos de positivação da boa-fé subjetiva no Código Civil podem ser encontrados nos arts. 1.242 e 1.561, dentre outros. (AGUIAR JÚNIOR, 2004, p. 243). 
estado de consciência da pessoa ${ }^{4}$, servindo à proteção daquele que tem a consciência de estar agindo conforme o direito, apesar de ser outra a realidade. Nas palavras de Ustárroz (2007, p. 71):

aquele que age de acordo com a boa-fé subjetiva não tem consciência e não deseja que, de seu agir, decorra prejuízo a outrem. A ação, ainda que seja contrária ao direito, é tida pelo agente como lícita, e esse sentimento o anima para determinar sua conduta.

A dificuldade para se buscar uma melhor precisão técnica que facilite a compreensão da noção de boa-fé subjetiva pode ser bem ilustrada na lúcida ponderação de Comte-Sponville (1999, p. 106):

[...] Dir-se-á que a boa-fé não prova nada; estou de acordo. Quantos canalhas sinceros, quantos horrores consumados de boa-fé? [...] Um canalha autêntico é um canalha: de que adianta sua autenticidade? Como a fidelidade ou a coragem, a boa-fé tampouco é uma virtude suficiente ou completa. Ela não substitui a justiça, nem a generosidade, nem o amor. Mas que seria uma justiça de má-fé? Que seriam um amor ou uma generosidade de má-fé? Já não seriam justiça, nem amor, nem generosidade, a não ser que corrompidos à força de hipocrisia, de cegueira, de mentira. Nenhuma virtude é verdadeira, ou não é verdadeiramente virtuosa sem essa virtude de verdade. Virtude sem boa-fé é má-fé, não é virtude.

$4 \quad$ Em relação à boa-fé subjetiva existe dissenso doutrinário sobre os requisitos necessários à sua configuração. Para os partidários de uma concepção puramente psicológica, basta a ignorância de determinado fato ou estado de coisas, abstraindo-se qualquer aferição de diligência do sujeito como dado relevante. Já na concepção ética, "o desconhecimento do vício que torna ilegítimo o exercício da posição jurídica ou a aquisição do direito não pode ser culposo" (DUARTE, 2004, p. 414). Sem dúvida, é mais fácil perquirir as circunstâncias fáticas que permitiriam ao figurante do contrato ter ciência do vício que tornava ilegítimo o exercício de sua posição jurídica do que saber o que se passou em seu íntimo. Resta saber qual o grau de diligência a ser exigido, sendo a melhor alternativa aquela que leva em consideração as condições pessoais do agente, como seu nível econômico-social, educação, experiência profissional etc. 
Embora seja possível distinguir as espécies, deve-se anotar que não existe independência entre elas, pois "divergem entre si na mesma medida em que se complementam" (LEWICKI, 2000, p. 57) 5 .

O Código Civil pátrio tratou da boa-fé em diversos dispositivos, merecendo, todavia, destaque para o tratamento a ela conferido nos arts. 113, 187 e 422, que espelham a diversidade de funções que ela exerce em nosso ordenamento ${ }^{6}$.

Ainda na Parte Geral do $\mathrm{CC} / 02^{7}$, merece destaque a função interpretativa da boa-fé, prescrevendo o legislador que os negócios jurídicos devem ser interpretados "conforme a boa-fé e os usos do lugar de sua celebração", como também a função de controle, servindo de standard, arquétipo social adequado, para limitação do exercício

5 Aldemiro Rezende Danas Júnior afirma que a boa-fé objetiva engloba a subjetiva, uma vez que "se o sujeito não desconhece a circunstância, nem ao menos chegou a criar a justa expectativa, não se formou em seu interior a confiança” (LEWICKI, 2000, p. 28, nota de rodapé 3).

6 Há quem sustente também uma quarta função para a boa-fé, relacionando-a como "autorização para decisão por equidade". Sobre o tema, ver: Marques (2011, p. 221).

7 O Código Civil Suíço também trata da boa-fé em sua parte geral, não havendo dúvidas de sua aplicação a todos os demais dispositivos previstos na parte especial da mencionada lei. Vale aqui transcrever o teor do art. $2^{\circ}$ ("Chacun est tenu d'exercer ses droits et d'exécuter ses obligations selon les règles de la bonne foi") e art. $3^{\circ}$ ("La bonne foi est présumée, lorsque la loi en fait dépendre la naissance ou les effets d'un droit').

8 O Código Civil Alemão (BGB), pode-se identificar idêntica função em seu § 242, que trata do tema da seguinte forma: "Der Schuldner ist verpflichtet, die Leistung so zu bewirken, wie Treu und Glauben mit Rücksicht auf die Verkehrssitte es erforder". Numa tradução livre, o referido dispositivo pode ser assim compreendido: "Um devedor tem o dever de agir (ou de se comportar) de acordo com as exigências da boa-fé, tendo em consideração as práticas correntes". Vale destacar o teor do Enunciado 409 da V Jornada de Direito Civil, promovida pelo Conselho da Justiça Federal, relativo ao art. 113 do CC/02: "Os negócios jurídicos devem ser interpretados não só conforme a boa-fé e os usos do lugar de sua celebração, mas também de acordo com as práticas habitualmente adotadas entre as partes". 
abusivo ou disfuncional de direitos, conforme determina o art. $187^{9}$ do referido diploma ${ }^{10}$.

No campo do direito obrigacional ${ }^{11}$, surge mais uma das funções comumente atribuídas à boa-fé, dessa vez relacionada à criação de novos deveres no tráfego jurídico. Trata-se da função integrativa (art. 422), a qual, para Roppo (2009), permite determinar a medida e a qualidade das obrigações que resultam do próprio contrato, numa lógica de respeito da autonomia privada.

\section{A função integrativa da boa-fé objetiva}

Para Couto e Silva (2006), o princípio da boa-fé revela-se como delineador do campo a ser preenchido pela interpretação integradora, no qual serão investigados os propósitos e as intenções dos contratantes, razão pela qual não indica qual conduta a ser adotada pelas partes de uma relação negocial, mas como estas devem se comportar. Nesse sentido, Negreiros (1998, pp. 222-223) anota que:

o princípio da boa-fé, como resultante necessária de uma ordenação solidária das relações intersubjetivas, patrimoniais ou não, projetada pela Constituição, configurase muito mais do que como fator de compreensão da autonomia privada, como um parâmetro para a sua

9 Art. 187: "também comete ato ilícito o titular de um direito que, ao exercê-lo, excede manifestamente os limites impostos pelo seu fim econômico ou social, pela boa-fé ou pelos bons costumes". Vale destacar o teor do Enunciado 413 da V Jornada de Direito Civil, promovida pelo Conselho da Justiça Federal, relativo ao art. 187 do CC/02: "Os bons costumes previstos no art. 187 do CC possuem natureza subjetiva, destinada ao controle da moralidade social de determinada época, e objetiva, para permitir a sindicância da violação dos negócios jurídicos em questões não abrangidas pela função social e pela boa-fé objetiva".

10 Em sentido semelhante, no Código Civil Argentino, o tema é tratado no art. 1.071 da seguinte forma: "El ejercicio regular de un derecho propio o el cumplimiento de una obligación legal no puede constituir como ilícito ningún acto. La ley no ampara el ejercicio abusivo de los derechos. Se considerará tal al que contraríe los fines que aquélla tuvo en mira al reconocerlos o al que exceda los límites impuestos por la buena fe, la moral y las buenas costumbres".

11 No Código Civil Espanhol, a exigência da boa-fé no campo obrigacional está disposta no art. 1.258: "Los contratos se perfeccionan por el mero consentimiento, y desde entonces obligan, no sólo al cumplimiento de lo expresamente pactado, sino también a todas las consecuencias que, según su naturaleza, sean conformes a la buena fe, al uso y a la ley". 
funcionalização à dignidade da pessoa humana, em todas as suas dimensões.

Em outras palavras, o dever geral da boa-fé é atendido quando as partes desempenham suas condutas de modo honesto, leal e correto, evitando causar danos ao outro (dever de proteção) e garantindo o conhecimento de todas as circunstâncias relevantes para a negociação (dever de informação) - comportamento que faz florescer laços de confiança entre os contratantes ${ }^{12}$. A boa-fé, por conseguinte, exige a adoção de uma postura proativa, traduzida em esmero, dedicação e cooperação na relação obrigacional. Enfim, tudo o que se espera de uma fraterna convivência.

A boa-fé requer um relacionamento particularizado entre dois sujeitos, vale dizer, um contato social qualificado, caracterizado pelo estreitamento da relação, pelas expectativas criadas e as vulnerabilidades engendradas, permitindo a interação comunicativa que gera a confiança (RIBEIRO, 2007).

A exata compreensão desse instituto não deve se limitar ao desenvolvimento de obrigações negativas. Dito de outro modo: não basta que cada um dos figurantes da relação obrigacional se abstenha de praticar atos que reduzam as possibilidades da outra parte de obter o máximo de proveito da prestação; a boa-fé prescreve a obrigação de cada um dos sujeitos de realizar tudo quanto esteja ao seu alcance para assegurar à contraparte o resultado útil almejado, independentemente de tais condutas estarem expressamente previstas no contrato.

Por isso, seu conceito não pode ser encontrado na análise do texto legal, mas na decisão judicial que aprecia como deve ocorrer sua

12 Lôbo (2006) faz referências ao pensamento de Cordeiro (2011). É interessante destacar que a noção de boa-fé exprime um imperativo ético, ou seja, encerra a ideia de um comportamento ideal a ser atingido, não se confundindo com a noção de bons costumes, muito mais próxima do campo da moral que é extraída da realidade social. Couto e Silva (2006, p. 35) sustenta que "os bons costumes referem-se a valores morais indispensáveis ao convívio social, enquanto a boa-fé tem atinência com a conduta concreta dos figurantes na relação jurídica. Assim, quem convenciona não cumprir determinado contrato age contra os bons costumes, decorrendo a nulidade do negócio jurídico. De outro lado, quem deixar de indicar circunstância necessária ao fiel cumprimento da obrigação terá apenas violado dever de cooperação para com o outro partícipe do vínculo, inexistindo, porém, infringência à cláusula dos bons costumes". 
aplicação, levando em consideração as circunstâncias do caso concreto e exigindo, para sua compreensão, mais da análise da atividade judicial do que da análise de textos doutrinários.

Para agravar tal dificuldade, está-se diante de uma categoria da teoria geral do direito que não se limita apenas ao campo do direito obrigacional, podendo ser utilizada, por exemplo, no direito das coisas (v.g., arts. 1.201 e 1.826) e no direito de família ${ }^{13}$ (art. 1.561), o que demonstra sua tendência expansionista ${ }^{14}$, uma vez que hoje ela também é largamente utilizada no direito processual e no direito administrativo. Apesar de escapar dos objetivos do presente trabalho, não se pode deixar de registrar o interessante precedente que demonstra a aplicação do princípio da boa-fé no campo do direito processual em relação às condutas do próprio magistrado que conduzia o processo, preservando o comportamento prévio que criou nas partes uma legítima expectativa.

RECURSO ESPECIAL - EMBARGOS À EXECUÇÃO PRELIMINAR DE INTEMPESTIVIDADE - INEXISTÊNCIA - ART. 244, DO CÓDIGO DE PROCESSO CIVIL PREQUESTIONAMENTO - AUSÊNCIA - INCIDÊNCIA DA SÚMULA 211/STJ - PREPARO - AUSÊNCIA - INTIMAÇÃO PESSOAL - DESNECESSIDADE - PRECEDENTES DESTA CORTE SUPERIOR - PORÉM, DETERMINADA A INTIMAÇÃO PARA RECOLHIMENTO DO PREPARO E DEVIDAMENTE CUMPRIDO - VIOLAÇÃO DO PRINCÍPIO DA CONFIANÇA (VENIRE CONTRA FACTUM PROPRIUM) - DECISÃO QUE EXTINGUE A DEMANDA, SEM JULGAMENTO DE MÉRITO - PRINCÍPIO DA BOAFÉ OBJETIVA - OBSERVÂNCIA - RECURSO ESPECIAL PARCIALMENTE CONHECIDO E, NESSA EXTENSÃO,

13 Sobre a aplicação da boa-fé no Direito de Família, interessante registrar recente decisão do Superior Tribunal de Justiça sobre o assunto: "Nas relações familiares, o princípio da boa-fé objetiva deve ser observado e visto sob suas funções integrativas e limitadoras, traduzidas pela figura do venire contra factum proprium (proibição de comportamento contraditório), que exige coerência comportamental daqueles que buscam a tutela jurisdicional para a solução de conflitos no âmbito do Direito de Família" (REsp 1087163/RJ, Rel. Ministra NANCY ANDRIGHI, TERCEIRA TURMA, julgado em 18/8/2011, DJe 31/8/2011).

14 Vale destacar o teor do Enunciado 414 da V Jornada de Direito Civil, promovida pelo Conselho da Justiça Federal, relativo ao art. 187 do CC/02: "A cláusula geral do art. 187 do Código Civil tem fundamento constitucional nos princípios da solidariedade, devido processo legal e proteção da confiança e aplica-se a todos os ramos do direito". 
PROVIDO. [...] III - A jurisprudência desta Corte Superior proclama que, na hipótese de oposição de embargos do devedor, sem a comprovação do recolhimento de preparo, o Juiz deve determinar o cancelamento da distribuição do processo e o arquivamento dos respectivos autos, independentemente de intimação pessoal. IV - Todavia, na espécie, a conduta do Juízo a quo revela-se contraditória e viola o princípio insculpido na máxima nemo potest venire contra factum proprium, na medida em que anteriormente determinou - quando não precisava fazêlo - a intimação para recolhimento do preparo e, ato contínuo, mesmo após o cumprimento de sua ordem, entendeu por bem julgar extinta a demanda, sem julgamento de mérito. $V$ - Tal atitude viola o princípio da boa-fé objetiva porque criou, na parte autora, a legítima expectativa de que, após o recolhimento do preparo, dentro do prazo estabelecido pelo Magistrado, suas razões iniciais seriam examinadas, observando-se 0 devido processo legal. VI - Determinada a intimação para recolhimento do preparo e figurando este devidamente cumprido, em tempo e modo oportunos, não é o caso de extinção dos embargos à execução, com base no art. 267, IV, do CPC. VII - Recurso especial parcialmente conhecido e, nessa extensão, provido. (Grifo original) (REsp. 1116574/ ES, Rel. Ministro Massami Uyeda, Terceira Turma, julgado em 14/4/2011, DJe 27/4/2011).

De igual modo, dessa vez no campo das relações entre o Estado e os particulares, é importante anotar a recente decisão do Superior Tribunal de Justiça, que, ao apreciar a questão da possibilidade de devolução de valores recebidos indevidamente por servidor público, apresentou alguns critérios de aferição da boa-fé no caso concreto ${ }^{15}$. Por conta disso, daqui em diante, utilizar-se-á sempre de decisões

15 AgRg no REsp. 1263480/CE, Rel. Ministro Humberto Martins, Segunda Turma, julgado em 01/9/2011, DJe 9/9/2011. Segundo o Relator: "A boa-fé não deve ser aferida no real estado anímico do sujeito, mas sim naquilo que ele exterioriza. Em bom vernáculo, para concluir se o agente estava ou não de boa-fé, torna-se necessário analisar se o seu comportamento foi leal, ético, ou se havia justificativa amparada no direito. Busca-se, segundo a doutrina, a chamada boa-fé objetiva. 4. Na análise de casos similares, o Superior Tribunal de Justiça tem considerado, ainda que implicitamente, um elemento fático como decisivo na identificação da boa-fé do servidor. Trata-se da legítima confiança ou justificada expectativa, que o beneficiário adquire, de que valores recebidos são legais e de que integraram em definitivo o seu patrimônio". 
recentes dos Tribunais para melhor compreender o desenvolvimento da boa-fé em nossa experiência jurídica.

À medida que as relações sociais e econômicas vão se mostrando cada vez mais complexas, os deveres relativos ao adimplemento dos vínculos obrigacionais delas decorrentes se ampliam, desdobrando-se em diversos matizes e podendo surgir antes mesmo de vir a se concretizar a obrigação, ou mesmo hipóteses nas quais a obrigação nem virá a se concretizar (DANTAS JUNIOR, 2008, p. 1663). Tais deveres também se manifestam ao longo de toda a existência da relação, orientando-se sempre pela busca do melhor proveito possível, o que pode ensejar que alguns de seus aspectos perdurem mesmo após o adimplemento das prestações principais.

Desse modo, a exigência da boa-fé no comportamento das partes impõe limites objetivos ao tráfego jurídico, desde o período pré-contratual (in contraendo) até mesmo após o encerramento do negócio (deveres pos factum finitum), ensejando uma verdadeira transeficácia da relação contratual, cuja intensidade é inversamente proporcional ao espaço de autonomia privada reservado aos contratantes ${ }^{16}$.

Em relação aos deveres e à exigência de boa-fé em todas as fases do desenvolvimento da relação jurídica obrigacional, vale destacar o teor do Enunciado 170 da III Jornada de ireito Civil, promovida pelo Conselho da Justiça Federal: "A boa-fé objetiva deve ser observada pelas partes na fase de negociações preliminares e após a execução do contrato, quando tal exigência decorrer da natureza do contrato".

Justifica-se a importância da afirmação da aplicação do dever geral de boa-fé objetiva na fase pré-contratual ${ }^{17}$ e até mesmo após a execução

16 Desse modo, "quanto maior o peso da horizontalidade, maior o espaço da autonomia privada e, consequentemente, menor a intensidade da aplicação da boa-fé" (LÔBO, 2011a, p. 83). O que se busca explicar é que, na aplicação do princípio da boa-fé, devem ser considerados o momento e o lugar em que se realiza a transação, para se quantificar o nível de liberdade dos contratantes quando da realização do negócio.

17 Para Cavalieri Filho (2010, p. 300), "o espaço da responsabilidade pré-contratual é aquele em que os contatos já se iniciaram, mas o contrato ainda não se realizou". 
do contrato pelo fato de o teor do art. 422 do Código Civil exigir que se guarde a boa-fé "na conclusão do contrato, como em sua execução". No entanto, deve-se tomar cuidado para que uma interpretação literal do enunciado (que se refere ao dever de observar a boa-fé "quando tal exigência decorrer da natureza do contrato") não restrinja sua utilização aos deveres principais e acessórios da relação obrigacional.

Nesse sentido, é mais clara a disciplina da matéria de responsabilidade pré-contratual no Código Civil Italiano, que, em seu artigo 1.337, assegura que a boa-fé é exigível desde o desenvolvimento das negociações preliminares ${ }^{18}$.

Como visto no item anterior, a relação obrigacional complexa exige a observância de deveres laterais justamente hauridos, por construção doutrinária e jurisprudencial, do disposto no art. 422 do Código Civil, cuja importância reside no fato de ter positivado o dever geral de boa-fé, facilitando o trabalho do intérprete quando de sua concretização. Para ilustrar, vale transcrever a decisão do Superior Tribunal de Justiça sobre a responsabilidade civil pós-contratual:

CIVIL E PROCESSO CIVIL. CONTRATOS. DISTRIBUIÇÃO. CELEBRAÇÃO VERBAL. POSSIBILIDADE. LIMITES. RESCISÃO IMOTIVADA. BOA-FÉ OBJETIVA, FUNÇÃO SOCIAL DO CONTRATO E RESPONSABILIDADE PÓSCONTRATUAL. VIOLAÇÃO. INDENIZAÇÃO. CABIMENTO. DANOS MORAIS E HONORÁRIOS ADVOCATÍCIOS. REVISÃO. POSSIBILIDADE, DESDE QUE FIXADOS EM VALOR IRRISÓRIO OU EXORBITANTE. SUCUMBÊNCIA. DISTRIBUIÇÃO. CRITÉRIOS. [...] 3. A complexidade da relação de distribuição torna, via de regra, impraticável a sua contratação verbal. Todavia, sendo possível, a partir das provas carreadas aos autos, extrair todos os elementos

18 Eis o texto do art. 1.337 do Código Civil Italiano: "Le parti, nello svolgimento delle trattative e nella formazione del contratto, devono comportarsi secondo buona fede". Do mesmo modo, o Código Civil Português (art. 227) assim dispõe: "1. Quem negoceia com outrem para conclusão de um contrato deve, tanto nos preliminares como na formação dele, proceder segundo as regras da boa fé, sob pena de responder pelos danos que culposamente causar à outra parte". 
necessários à análise da relação comercial estabelecida entre as partes, nada impede que se reconheça a existência do contrato verbal de distribuição. 4. A rescisão imotivada do contrato, em especial quando efetivada por meio de conduta desleal e abusiva - violadora dos princípios da boa-fé objetiva, da função social do contrato e da responsabilidade pós-contratual - confere à parte prejudicada o direito à indenização por danos materiais e morais. 5. Os valores fixados a título de danos morais e de honorários advocatícios somente comportam revisão em sede de recurso especial nas hipóteses em que se mostrarem exagerados ou irrisórios. Precedentes. [...] 7. Recurso especial não provido. (REsp. 1255315/SP, Rel. Ministra Nancy Andrighi, Terceira Turma, julgado em 13/9/2011, DJe 27/9/2011).

Vale esclarecer que, em relação à pós-eficácia da relação jurídica obrigacional, devem-se afastar aqueles deveres ajustados previamente pelas partes, ainda que tenham sua execução exigida após o cumprimento da obrigação principal, pois, nessa hipótese, ainda permanecem vinculados à vontade das partes. Para caracterizar a póseficácia da relação obrigacional, basta avaliar se o escopo contratual foi frustrado sob o pretexto de que a obrigação se extinguiu (CORDEIRO, 2011, p. 630).

No campo da pós-eficácia, comumente se verifica a tentativa de se evitar a ocorrência de dano tão logo detectado um problema (recall), através de assistência técnica, prestação de contas e fornecimento de peças de reposição.

\section{Os deveres que decorrem da boa-fé objetiva}

Nos tópicos anteriores, enfatizou-se a necessidade de as partes se comportarem segundo le regole dela correttezza, anotando-se que o tratamento dogmático dos deveres gerais de conduta ultrapassou a mera exigência de proteção dos figurantes e do seu patrimônio para exigir um comportamento voltado à obtenção da plena satisfação da 
obrigação, abrangendo deveres de informação (esclarecimento) e de lealdade, em cuja base de sustentação está a boa-fé. Decorreriam da boa-fé os seguintes deveres ${ }^{19}$ :

a) Dever de proteção, que impõe às partes a obrigação de prevenir danos ${ }^{20}$, tanto em relação ao objeto da prestação como em relação às esferas jurídicas das partes e, eventualmente, de terceiros, e se desdobra na exigência da manutenção de um comportamento diligente; exigência de velar pelo adequado fluxo da relação jurídica obrigacional com cuidado, previdência e segurança.

b) Dever de informação, que impõe às partes a obrigação de advertir, explicar, esclarecer, avisar e prestar contas sempre que se fizer necessário, em especial quando da ocorrência de circunstância ainda desconhecida da outra parte, mas necessária ao pleno desenvolvimento da relação jurídica obrigacional na direção do mesmo adimplemento possível.

c) Dever de cooperação, que impõe às partes a obrigação de mútuo auxílio na superação de eventuais obstáculos surgidos em qualquer fase do desenvolvimento da relação jurídica obrigacional, por vezes confundindo-se com a exigência de fidelidade e lealdade entre as partes contratantes, que, dentre outras condutas, pode ensejar o dever de omissão e segredos de informações obtidas no iter obrigacional para preservação de interesses comuns ou específicos de um dos figurantes.

19 O tema é retratado por diversos autores, dentre os quais cumpre citar Cordeiro (2011, p. 546-564 e 648-649); Martins-Costa, (1999, p. 65-67); Dantas Junior (2008, p. 165-167); Couto e Silva (2006, p. 30-38); Jaluzot (2001, p. 511-515).

20 A lisura negocial que o princípio impõe se traduz, nesse contexto, "no dever de não se prevalecer oportunisticamente de um conteúdo contratual que, em face das novas e imprevistas circunstâncias, se tornou excessivamente oneroso ou inútil para a outra parte" (RIBEIRO, 2007, p. 211). Por essa razão, o não cumprimento desse dever de proteção justifica uma decisão judicial corretiva (ou extintiva) da situação concreta. 
Ainda em referência à exigência de lealdade, resta destacar sua íntima relação com a confiança depositada no outro contratante, originada de comportamentos anteriormente adotados pelos sujeitos, os quais, devido a tal postura, passaram a acreditar em um determinado desdobramento da situação, não podendo a expectativa fundada em elementos fáticos aferíveis objetivamente ser violada sem qualquer justificativa ${ }^{21}$.

Um claro exemplo do reconhecimento judicial da obrigatoriedade dos deveres laterais (rectius gerais) da relação obrigacional pode ser visto no caso transcrito a seguir:

RECURSO ESPECIAL. CONTRATO INTERNACIONAL DE PRESTAÇÃO DE SERVIÇOS PARA A AMPLIAÇÃO DE USINA TERMELÉTRICA NACIONAL. PAGAMENTO EM LIRAS ITALIANAS. REMESSA VIA BANCO CENTRAL. VIOLAÇÃO DO DEVER DE COOPERAÇÃO. MORA DA PRESTADORA DE SERVIÇOS ITALIANA RECONHECIDA (MORA 'CREDITORIS'). I - Contratação, por concessionária de energia elétrica nacional, de sociedade italiana para a prestação de serviços relacionados à ampliação de Usina Termelétrica no Estado de Santa Catarina. II - Remuneração convencionada em liras italianas nos termos do art. $2^{\circ}$ do Decreto-lei 857/69, remetida via Banco Central do Brasil. III -

21 Sobre o tema, vale transcrever a ementa de recente decisão do Superior Tribunal de Justiça: "PROCESSUAL CIVIL E CIVIL. FUNGIBILIDADE RECURSAL. RECURSO RECEBIDO COMO AGRAVO REGIMENTAL. SEGURO DE VIDA. NÃO RENOVAÇÃO. FATOR DE IDADE. OFENSA AOS PRINCÍPIOS DA BOA-FÉ OBJETIVA, DA COOPERAÇÃO, DA CONFIANÇA E DA LEALDADE. AUMENTO. EQUILÍBRIO CONTRATUAL. CIENTIFICAÇÃO PRÉVIA DO SEGURADO. 1. Em nome dos princípios da economia processual e da fungibilidade, admitem-se como agravo regimental os embargos de declaração opostos a decisão monocrática proferida pelo relator do feito no Tribunal. 2. Na hipótese em que o contrato de seguro de vida é renovado ano a ano, por longo período, não pode a seguradora modificar subitamente as condições da avença nem deixar de renová-la em razão do fator de idade, sem que ofenda os princípios da boa-fé objetiva, da cooperação, da confiança e da lealdade. 3. A alteração consistente em aumentos necessários ao equilíbrio contratual deve ser efetuada de maneira gradual, da qual o segurado tem de ser previamente cientificado. 4. Embargos de declaração recebidos como agravo regimental, ao qual se nega provimento." (EDcl no REsp. 1159632/RJ, Rel. Ministro João Otávio de Noronha, Quarta Turma, julgado em 9/8/2011, DJe 19/8/2011). Sobre o assunto, ver também REsp. 866.840/SP, Rel. Ministro Luis Felipe Salomão, Rel. p/ Acórdão Ministro Raul Araújo, Quarta Turma, julgado em 7/6/2011, DJe 17/8/2011). 
Não-pagamento, pela concessionária, de notas e faturas de serviço em razão da impossibilidade de remessa dos valores à Itália ante a não-regularização da situação da prestadora dos serviços junto ao Banco Central do Brasil.[...] V Exigidos documentos relativos aos seus funcionários, pertence à prestadora de serviços italiana, em que pese a omissão contratual, a obrigação acessória, derivada do princípio da boa-fé objetiva, de, em cooperação com a concessionária, regularizar a situação, permitindo a remessa dos valores. [...] (REsp. 857.299/SC, Rel. Ministro Paulo de Tarso Sanseverino, Terceira Turma, julgado em 3/5/2011, DJe 13/6/2011). (Grifou-se)

Tratando da boa-fé como norma de validade, Ribeiro (2007) afirma que ela constitui um fator de determinação dos efeitos do vínculo obrigacional, destacando ainda que, em qualquer de suas modalidades operativas, a boa-fé está relacionada à prevenção de danos, tanto daqueles que poderiam resultar da violação de bens já integrantes da esfera jurídica de qualquer dos participantes da relação, como daqueles relacionados a não consecução (ou consecução imperfeita) dos fins que justificaram a constituição da relação jurídica.

Nesse contexto, seria possível vislumbrar mais um dever decorrente da boa-fé: a obrigação de mitigação. Ao tratar da doutrina da mitigação, Aguiar Júnior (2004) anota que deve o credor colaborar, apesar da inexecução do contrato, para que não se agrave, pela sua ação ou omissão, o resultado danoso resultante do incumprimento, pois não é possível pretender o ressarcimento de perda que poderia ter sido evitada, mas não o foi, por injustificada ação ou omissão. Sobre o dever de mitigar o prejuízo, aduz Gomes (2005, p. 294):

Feita a ponderação de valores, no momento em que se estabelece a indenização, deve-se ter em conta se o autor do dano adotou atitude indiscutivelmente solidária e cooperativa para com a vítima. Não bastam meras exteriorizações de boas intenções; é fundamental que estas se materializem em atos concretos, efetivos e relevantes, no sentido de minorar os efeitos maléficos do próprio comportamento danoso. Cabe igualmente cogitar o 
agravamento da indenização se o causador do dano não tiver se solidarizado com a vítima, no sentido indicado.

Dentro dessa linha de raciocínio, pode-se destacar o teor do Enunciado 169, redigido na III Jornada de Direito Civil, promovida pelo Conselho da Justiça Federal: "o princípio da boa-fé objetiva levar o credor a evitar o agravamento do próprio prejuízo". Apesar da importância prática do tema, é possível enquadrar tal dever dentro da obrigação de cooperação - perspectiva mais ampla -, que exige a adoção de uma conduta positiva dirigida à proteção dos interesses do outro.

Pode-se destacar outra questão de fundamental importância para a correta delimitação da extensão dos deveres exigíveis em uma relação obrigacional: até que ponto podem ser exigidos sacrifícios do sujeito da relação jurídica obrigacional para que não seja violado o mencionado dever de cooperação?

O limite pode ser encontrado na preservação dos próprios interesses do sujeito, ou seja, a pretexto de atendimento do dever de cooperação, não se pode exigir sacrifício desmesurado, causando nítido desequilíbrio entre as partes ${ }^{22}$ (DANTAS JUNIOR, 2008, p. 168-170). Analisando o tema, Ustárroz (2007, p. 85) adverte que:

o comportamento segundo a boa-fé deverá ser pensado a partir das circunstâncias concretas de ambos os contratantes, pois nada adiantaria salvar o interesse de um para comprometer o do outro parceiro. Portanto, não se afigura razoável exigir determinada conduta, ao pretexto de adimplir deveres laterais oriundos da boa-fé, se esse fato

22 Ainda sobre o tema, vale transcrever o § 275/2 do Código Civil Alemão: "Der Schuldner kann die Leistung verweigern, soweit diese einen Aufwand erfordert, der unter Beachtung des Inhalts des Schuldverhältnisses und der Gebote von Treu und Glauben in einem groben Missverhältnis zu dem Leistungsinteresse des Gläubigers steht. Bei der Bestimmung der dem Schuldner zuzumutenden Anstrengungen ist auch zu berücksichtigen, ob der Schuldner das Leistungshindernis zu vertreten hat". Numa tradução livre, o referido dispositivo poderia ser assim compreendido: "o devedor pode recusar o cumprimento na medida em que o seu desempenho (prestação) exige despesa e esforço, que, tendo em conta a natureza da obrigação e as exigências da boa-fé, é totalmente desproporcional ao interesse do credor. Quando é determinado que os esforços podem ser razoavelmente exigido do devedor, deve também ser tida em conta se ele é responsável pelo obstáculo ao desempenho". 
importar sensível prejuízo, de modo que a própria causa do negócio jurídico seja afetada. Deve estar presente uma ponderação entre os interesses em jogo, a fim de que o intérprete conclua até que medida é conveniente e legal exigir-se do contraente um comportamento que lhe causará prejuízo ${ }^{23}$.

O objetivo, neste ponto do trabalho, é tentar apresentar uma possível classificação dos deveres que decorrem da boa-fé objetiva, destacando, desde logo, que qualquer divisão serve apenas para fins didáticos, buscando uma melhor sistematização do assunto, uma vez que a linha divisória de cada uma das espécies a seguir apresentadas é tênue e marcada pela imprecisão, pois não raro a dinâmica da relação obrigacional exige a combinação de deveres diversos na direção do melhor adimplemento possível ${ }^{24}$.

Anote-se, entretanto, uma característica comum a todos os deveres gerais aqui analisados: sua independência ante as prestações principais, pois o fato de ser impossível o cumprimento da prestação principal não impede o surgimento dos demais efeitos que podem decorrer da relação jurídica obrigacional.

23 Prosseguindo o raciocínio, aduz Ustárroz (2007, pp. 86-87): "Cumpre não perder de vista que, quanto maiores os deveres decorrentes da aplicação do princípio da boa-fé objetiva, mais cautela as partes irão tomar antes de entabular qualquer relação. E este fenômeno, se mal administrado [desvinculado do caso concreto e do paradigma do sistema calcado em princípios], poderá inibir o tráfego jurídico, fato que traria nefasta consequência para a comunidade. [...] de nada adiantaria que uma parte assumisse um comportamento que the ofertasse prejuízos, ainda que salvaguardasse 0 interesse alheio. A complexidade da obrigação estaria sendo atingida da mesma forma, apenas alterando o patrimônio lesado [...] a boa-fé, assim como os demais princípios, nunca podem ser lidos isoladamente, e cada solução deve, dentro das contingências e particularidades do problema analisado, salvaguardar todos os direitos envolvidos, conciliando a importância do elemento vontade com a confiança".

24 Dantas Junior (2008, p. 172) cita um bom exemplo da dificuldade de precisar os limites de tais deveres: "a colocação de um aviso, indicando que o piso está molhado, e, por isso, escorregadio, atende não apenas ao dever de informação, mas também ao dever de proteção aos clientes, ainda que estes ainda não tenham comprado qualquer produto ou que, já tendo pago o preço e recebido a mercadoria, seus contratos já tenham sido extintos". 
Registre-se um exemplo extremo para corroborar com tal afirmação. Imagine que alguém privado de discernimento devido a uma doença mental - portanto, absolutamente incapaz nos termos do disposto no inciso II do art. $3^{\circ}$ do $\mathrm{CC} / 02$ - contratasse, pelo telefone, os serviços de uma empresa de mudanças. Chegando o dia combinado, os funcionários da empresa iniciam a remoção do mobiliário antes que o gerente detecte a causa da invalidade do contrato. Mesmo tendo sido reconhecida a nulidade do negócio pactuado, se durante a movimentação das peças algumas foram danificadas, persiste o dever de indenizar pela violação do dever geral de proteção ao patrimônio do outro figurante.

Analisada a função integrativa da boa-fé objetiva, resta abordar a função de controle, em especial, o exercício disfuncional de uma posição jurídica ${ }^{25}$.

\section{A função de controle da boa-fé objetiva: considerações sobre o exercício disfuncional de uma posição jurídica}

\subsection{Venire contra factum proprium}

O exercício de direitos subjetivos apresenta limites, pois não pode ofender os interesses da comunhão social (MARQUES, 2011, p. 217). Do dever geral de boa-fé objetiva derivam, por exemplo, o dever de não agir contra os atos próprios (venire contra factum proprium) e o dever de informar, que influenciam quando do controle judicial de cláusulas penais, sobretudo nas relações de consumo, uma vez que "contribui para determinar o 'que' e o 'como' da prestação e, ao relacionar ambos os figurantes do vínculo, fixa, também, os limites da prestação" (COUTO E SILVA, 2006, p. 34).

25 Vale destacar o teor do Enunciado 412 da V Jornada de Direito Civil, promovida pelo Conselho da Justiça Federal, relativo ao art. 187 do CC/02: "As diversas hipóteses de exercício inadmissível de uma situação jurídica subjetiva, tais como supressio, tu quoque, surrectio e venire contra factum proprium são concreções da boa-fé objetiva". 
Explica Cordeiro (2011, p. 250-251) que a locução venire contra factum proprium tem origem canônica e representa a reprovação social e moral que recai sobre aquele que assume comportamento contraditório. Com vasto campo de atuação, seu estudo configura a denominada "Teoria dos Atos Próprios", através da qual se analisam dois comportamentos de uma mesma pessoa, lícitos em si e diferidos no tempo. O primeiro (factum proprium) é contrariado pelo segundo (venire) (NANNI, 2008, p. 738-772).

O fundamento da proibição do exercício de uma posição jurídica em contradição com o comportamento anteriormente assumido pelo exercente é a confiança ${ }^{26}$. Trata-se de um abuso de direito (art. 187) por violação à boa-fé (SCHREIBER, 2005), que enseja duas consequências: além de impedir o exercício do comportamento posterior, também gera o dever de reparar eventuais prejuízos provocados pela contradição ${ }^{27}$.

Assim, a noção de confiança aqui empregada visa à proteção de interesses que transcendem o indivíduo. Não se trata de proteger o destinatário, e sim a segurança do tráfico. Cuida, portanto, de salvaguardar as expectativas contratuais dos que se aproximam e contratam (NALIN, 2001), valorizando o caráter social do negócio jurídico.

Aexpressão em análise, portanto, denota uma evidente contradição, não sendo admitido pelo sistema "comportar-se contra os seus próprios atos”, em face da falta de coerência, não obstante este não seja o seu único elemento característico ${ }^{28}$. Ponto decisivo é a demonstração da

26 Nesse sentido, o Enunciado $n^{\circ} 362$ das Jornadas de Direito Privado do Conselho da Justiça Federal: "Art. 422. A vedação do comportamento contraditório (venire contra factum proprium) funda-se na proteção da confiança, tal como se extrai dos arts. 187 e 422 do Código Civil".

27 Vale aqui a lição de Lorenzetti (2000, p. 23): "como principio jurídico y regla hermenéutica tanto la confianza como la apariencia significan que se da primacía a lo objetivamente declarado; quien crea una apariencia, se hace prisionero de ella".

28 Dantas Júnior (2008) anota que, em muitas ocasiões, a falta de coerência do sujeito não é proibida nem gera consequências jurídicas quando ocorre. No Código Civil, encontramos dispositivos que permitem a retratação de uma proposta formulada entre ausentes, a revogação de um testamento que exprime situações nas quais a contrariedade, em si mesma, não é sancionada. 
deslealdade, uma vez que a finalidade aqui perseguida é a proteção de quem confiou, em termos justificados, na primeira conduta ${ }^{29}$. MartinsCosta (1999, p. 471) expõe com clareza seus elementos constitutivos:

O seu fundamento técnico-jurídico - e daí a conexão com a boa-fé objetiva - reside na proteção da confiança da contraparte, a qual se concretiza, neste específico terreno, mediante a configuração dos seguintes elementos, objetivos e subjetivos: (a) a atuação de um fato gerador de confiança, nos termos em que esta é tutelada pela ordem jurídica; (b) a adesão da contraparte - porque confiou - neste fato; (c) o fato de a contraparte exercer alguma atividade posterior em razão da confiança que nela foi gerada; (d) o fato de ocorrer, em razão de conduta contraditória do autor do fato gerador da confiança, a supressão do fato no qual fora assentada a confiança, gerando prejuízo ou iniquidade insuportável para quem confiara

Anote-se que, quando isoladamente considerado, nenhum dos comportamentos em análise se mostra ilícito, razão pela qual somente é possível delimitar o campo de incidência do instituto se a conduta for considerada como o conjunto dos dois comportamentos mencionados.

\footnotetext{
ADMINISTRATIVO. CONTRATO DE GARANTIA CELEBRADO POR PARTES DISTINTAS DAQUELAS QUE AJUSTARAM O CONTRATO PRINCIPAL. COMPORTAMENTO INICIAL QUE VINCULOU O ATUAR NO MESMO SENTIDO OUTRORA APONTADO. QUEBRA DA CONFIANÇA. RESPONSABILIDADE. PROIBIÇÃO DE COMPORTAMENTO CONTRADITÓRIO (NEMO POTEST VENIRE CONTRA FACTUM PROPRIUM). [...] 4. Contudo, o presente caso apresenta uma peculiaridade que não pode ser ignorada. É que, como bem destacado pela Corte a quo, o ajuste entre a recorrente e o Banco Banorte S.A. tinha exatamente por fim dar garantia ao acordo entabulado entre a Universidade Federal do Paraná e a IBM WTC para o fornecimento de microcomputadores. 5. Deste modo, entender pela irresponsabilidade da IBM BRASIL resultaria em desprover de qualquer eficácia o contrato celebrado entre esta e a mencionada instituição bancária. Adotar um entendimento contrário à legitimidade da recorrente levar-nos-ia a uma questão indecifrável, a um verdadeiro paradoxo: para que serviria o contrato de garantia ante o inadimplemento do contrato principal? 6. Deve-se, portanto, atribuir função econômicoindividual ao ajuste, sobretudo diante da redação do art. 422 e do parágrafo único do art. 2.035 do Código Civil de 2002, os quais impõem aos negócios jurídicos - mesmo àqueles constituídos antes da entrada em vigor deste diploma -, a obediência à cláusula geral de ordem pública da boa-fé objetiva, a qual, por sua vez, sujeita ambos os contratantes à recíproca cooperação a fim de alcançar o efeito prático que justifica a própria existência do contrato. Sobretudo, também, porque a ninguém é dado vir contra o próprio ato, proibindo-se o comportamento contraditório (nemo potest venire contra factum proprium)." (REsp. 1217951/PR, Rel. Ministro Mauro Campbell Marques, Segunda Turma, julgado em 17/2/2011, DJe 10/3/2011).
} 
Apesar disso, faz-se necessário que o segundo comportamento não corresponda à violação de uma obrigação decorrente do primeiro (senão haveria hipótese de mero inadimplemento), que exige do intérprete considerar, no conjunto da obra, dois comportamentos que de per si são autônomos, vinculados entre si apenas pelo contexto da situação.

Tal entendimento pode ser bem evidenciado no julgamento transcrito a seguir, no qual restou definido que não existe pretensão indenizatória para aquele que adquire bem tendo conhecimento prévio das limitações impostas à propriedade. Ei-lo:

ADMINISTRATIVO. PARQUE ESTADUAL DA SERRA DO MAR. AQUISIÇÃO DE IMÓVEL APÓS IMPOSIÇÃO DE LIMITAÇÃO ADMINISTRATIVA. DIREITO À INDENIZAÇÃO. INEXISTÊNCIA. 1. Não cabe indenização pela limitação administrativa decorrente da criação do Parque Estadual da Serra do Mar, se o imóvel foi adquirido quando já incidiam as restrições impostas pelo Estado de São Paulo. 2. Viola o princípio da boa-fé objetiva o particular que adquire, por sua conta e risco, imóvel dentro de Unidade de Conservação (Parque Estadual), ciente das limitações impostas à propriedade, e, posteriormente, vem exigir indenização do Estado a pretexto dessas mesmas limitações. 3. Recurso Especial provido. (REsp. 686.410/ SP, Rel. Ministro Herman Benjamin, Segunda Turma, julgado em 6/11/2007, DJe 11/11/2009) ${ }^{30}$.

Recentemente, o Superior Tribunal de Justiça apreciou um caso no qual uma instituição financeira manejou embargos à execução movida por terceiro em desfavor de devedor comum, arguindo que o imóvel penhorado - o único de propriedade do devedor - era bem de família,

30 No mesmo sentido: "MEMORANDO DE ENTENDIMENTO. BOA-FÉ. SUSPENSÃO DO PROCESSO. O compromisso público assumido pelo Ministro da Fazenda, através de 'memorando de entendimento', para suspensão da execução judicial de dívida bancária de devedor que se apresentasse para acerto de contas gera no mutuário a justa expectativa de que essa suspensão ocorrerá, preenchida a condição. Direito de obter a suspensão fundado no principio da boa-fé objetiva, que privilegia o respeito à lealdade. Deferimento da liminar, que garantiu a suspensão pleiteada. Recurso improvido". (RMS 6.183/MG, Rel. Ministro Ruy Rosado de Aguiar, Quarta Turma, julgado em 14/11/1995, DJ 18/12/1995, p. 44.573). 
insuscetível, portanto, de constrição judicial. Não obstante, o objetivo com a adoção de tal demanda tinha finalidade bem diversa da proteção do patrimônio mínimo do devedor. Pretendia a instituição financeira livrar o imóvel da constrição alheia para que sobre ele recaísse apenas o ônus imposto por ela própria.

Ao contrário do débito contraído junto a terceiro, o devedor tomou empréstimo à instituição financeira para construção da própria casa objeto da constrição judicial. Nessa hipótese, apesar de oponível contra o terceiro credor, a impenhorabilidade do bem de família não é eficaz perante a instituição financeira, que está protegida pelo rol das exceções previstas na Lei 8.009/90. Os ministros repeliram a pretensão da instituição financeira anotando ser abusivo o comportamento do credor, que:

esgrime contra terceiro o instituto do bem de família, sabedor que contra ele próprio não será possível articular a mesma objeção, vendo-se livre, portanto, para excutir o mesmo imóvel que deveria estar a salvo, servindo de proteção ao direito de moradia constitucionalmente garantido.

Como consequência de tal entendimento, julgou-se que:

dispondo de outros meios para a satisfação de seu crédito, tal como a habilitação na execução alheia, comete abuso processual o credor que impede que terceiro execute imóvel, sob a alegação de constituir bem de família, para depois, em futura execução, frustrar, ele próprio, a finalidade do instituto, excutindo o mesmo bem pretensamente defendido. (AgRg no REsp. 709.372/RJ, Rel. Ministro Paulo de Tarso Sanseverino, Terceira Turma, julgado em 24/5/2011, DJe 3/6/2011).

Da análise deste caso, pode-se extrair mais uma das características do instituto do venire contra factum proprium, qual seja, a exigência de que o comportamento repercuta numa esfera jurídica alheia, provocando consequências jurídicas indesejáveis para o outro figurante da relação obrigacional. Em suma, o segundo comportamento deve piorar a situação do outro sujeito. 
Do reconhecimento do venire contra factum proprium podem advir diversas consequências jurídicas, as quais, assim como a conduta das partes, somente poderão ser aferidas no caso concreto. No entanto, pode-se vislumbrar, dentre outras possibilidades: (a) a manutenção do primeiro comportamento adotado pelo sujeito, (b) o afastamento de determinadas consequências dos atos praticados e (c) a indenização pelos danos causados ao sujeito em virtude da quebra de confiança verificada.

Anote-se, ainda, que é possível reconhecer a vedação de comportamento contraditório com uma das espécies de abuso do direito, não guardando, entretanto, ligação com a figura do estoppel, instituto que pertence ao direito anglo-saxão e apresenta natureza processual, estando relacionado à distribuição do ônus da prova.

Mas exercício disfuncional de uma posição jurídica ${ }^{31}$ não se limita à figura do venire contra factum proprium. Deve-se destacar a figura da exceptio doli, uma forma indireta de defesa processual através da

31 "DIREITO CIVIL. CONTRATO DE ARRENDAMENTO MERCANTIL PARA AQUISIÇÃO DE VEÍCULO (LEASING). PAGAMENTO DE TRINTA E UMA DAS TRINTA E SEIS PARCELAS DEVIDAS. RESOLUÇÃO DO CONTRATO. AÇÃO DE REINTEGRAÇÃO DE POSSE. DESCABIMENTO. MEDIDAS DESPROPORCIONAIS DIANTE DO DÉBITO REMANESCENTE. APLICAÇÃO DA TEORIA DO ADIMPLEMENTO SUBSTANCIAL. 1. É pela lente das cláusulas gerais previstas no Código Civil de 2002, sobretudo a da boa-fé objetiva e da função social, que deve ser lido o art. 475, segundo o qual '[a] parte lesada pelo inadimplemento pode pedir a resolução do contrato, se não preferir exigir-lhe o cumprimento, cabendo, em qualquer dos casos, indenização por perdas e danos'. 2. Nessa linha de entendimento, a teoria do substancial adimplemento visa a impedir o uso desequilibrado do direito de resolução por parte do credor, preterindo desfazimentos desnecessários em prol da preservação da avença, com vistas à realização dos princípios da boa-fé e da função social do contrato. 3. No caso em apreço, é de se aplicar a da teoria do adimplemento substancial dos contratos, porquanto o réu pagou: '31 das 36 prestações contratadas, $86 \%$ da obrigação total (contraprestação e VRG parcelado) e mais $\mathrm{R} \$ 10.500,44$ de valor residual garantido'. O mencionado descumprimento contratual é inapto a ensejar a reintegração de posse pretendida e, consequentemente, a resolução do contrato de arrendamento mercantil, medidas desproporcionais diante do substancial adimplemento da avença. 4. Não se está a afirmar que a dívida não paga desaparece, o que seria um convite a toda sorte de fraudes. Apenas se afirma que o meio de realização do crédito por que optou a instituição financeira não se mostra consentâneo com a extensão do inadimplemento e, de resto, com os ventos do Código Civil de 2002. Pode, certamente, o credor valer-se de meios menos gravosos e proporcionalmente mais adequados à persecução do crédito remanescente, como, por exemplo, a execução do título. 5. Recurso especial não conhecido." (REsp. 1051270/RS, Rel. Ministro Luis Felipe Salomão, Quarta Turma, julgado em 4/8/2011, DJe 5/9/2011). 
qual a parte demandada tem a possibilidade de afastar a pretensão do demandante - mesmo sem negar a existência do direito do autor -, demonstrando que tal direito foi exercido de modo doloso, mediante comportamento que não observou o dever geral de boa-fé.

No entanto, em que pese sua relevante importância histórica, tal instituto encerra uma noção demasiadamente ampla, razão pela qual atualmente cedeu espaço para violações mais específicas, que serão tratadas a seguir. Deve-se consignar apenas que a exceção de dolo não se confunde com a figura do venire contra factum proprium. Esta não pressupõe o dolo do sujeito para sua configuração.

\subsection{Supressio (Verwirkung)}

Consiste na redução do conteúdo obrigacional, pela inércia de uma das partes, em exercer direito ou faculdades, gerando legítima expectativa (PINTO, 2011, p. 315). Trata-se, por conseguinte, da inadmissibilidade do exercício de um direito (sua supressão) quando alguém deixa de exercê-lo durante longo tempo.

Contudo, não basta à sua configuração o simples retardamento no exercício do direito, não devendo tal instituto ser confundido com a prescrição e decadência - relacionadas apenas aos efeitos do tempo sobre as relações jurídicas ${ }^{32}$. Deve-se demonstrar, diante das circunstâncias do caso concreto, que a inércia teve como efeito gerar no outro figurante da relação obrigacional a confiança de que o direito em questão não mais seria exercido.

Dito de outra maneira, o fato de uma posição jurídica não ser exercida por certo tempo e seu exercício atentar contra a boa-fé pode provocar uma supressão de certas faculdades jurídicas, ou seja, não se

32 A demora de dez anos para ingressar com a ação de indenização não afasta a Súmula n 54 do STJ, em relação ao termo inicial dos juros moratórios, sendo o presente caso de responsabilidade extracontratual" (REsp. 991.371/RS, Rel. Ministro Aldir Passarinho Junior, Quarta Turma, julgado em 4/3/2010, DJe 29/3/2010). 
permite mais o exercício, pois se pune o exercício de posição que tenha sido deslealmente retardada (NANNI, 2008, p. 738-772; SCHREIBER, 2005, p. 178).

Como visto, a inatividade gera consequências que não se limitam à prescrição e à decadência. O que dificulta a sua compreensão é que não se pode definir a priori o lapso temporal suficiente para que a inatividade impeça o exercício do direito. Há que se analisar a deslealdade a partir da necessidade de se tutelar a confiança gerada na outra parte.

Recentemente, o Superior Tribunal de Justiça apreciou um caso relativo a um contrato de trato sucessivo no qual o credor, com o objetivo de evitar a majoração da parcela mensal do devedor, deixou de realizar a correção monetária da dívida para, dessa forma, garantir a manutenção do contrato. Decorridos seis anos da reiteração de tal conduta, passou a exigir retroativamente valores a título de correção monetária que vinha regularmente dispensando. O Tribunal entendeu pela impossibilidade de tal cobrança, suprimindo o correspondente direito à correção monetária para proteger a confiança estabelecida entre as partes ${ }^{33}$.

\subsection{Surrectio (Erwirkung)}

Este instituto corresponderia ao surgimento de direitos para aquele que está sendo protegido pelo instituto da supressio (DANTAS JUNIOR, 2008, p. 405). Traçando um comparativo ente os dois institutos, Cordeiro (2011, p. 824) afirma que:

O fenômeno da supressio, traduzido no desaparecimento de posições jurídicas que, não sendo exercidas em certas condições, durante determinado lapso de tempo, não mais podem sê-lo, sob pena de contrariar a boa-fé, corresponde a uma forma invertida de apresentar a realidade. A supressio é, apenas, o subproduto da formação, na esfera

33 REsp. 1202514/RS, Rel. Ministra Nancy Andrighi, Terceira Turma, julgado em 21/6/2011, DJe 30/6/2011. Vale destacar o seguinte trecho da ementa do julgado: "A supressio indica a possibilidade de redução do conteúdo obrigacional pela inércia qualificada de uma das partes, ao longo da execução do contrato, em exercer direito ou faculdade, criando para a outra a legítima expectativa de ter havido a renúncia àquela prerrogativa". 
do beneficiário, seja de um espaço de liberdade onde antes havia adstrinção, seja de um direito incompatível com o do titular preterido, seja, finalmente, de um direito que vai adstringir outra pessoa por, a esse mesmo beneficiário, se ter permitido actuar desse modo, em circunstâncias tais que a cessação superveniente da vantagem atentaria contra a boa-fé. O verdadeiro fenômeno em jogo é o da surrectio, entendida em sentido amplo. É nesta que devem ser procurados requisitos... Assim, o beneficiário tem de integrar uma previsão de confiança, ou seja, deve encontrar-se numa conjuntura tal que, objetivamente, um sujeito normal acreditaria quer no não exercício superveniente do direito da contraparte, quer na excelência do seu próprio direito.

Numa breve síntese, pode-se afirmar que a surrectio seria o inverso da supressio. Através de tal instituto, em face das circunstâncias do caso e da confiança estabelecida entre as partes, surge um direito que não existia antes, ou seja, a partir da cristalização de uma situação de repetida violação contratual ou legal, em circunstâncias objetivas, amplia-se o conteúdo obrigacional.

Há quem aponte o art. 330 do CC/02 como exemplo do instituto, uma vez que o pagamento reiteradamente feito em outro local faz presumir a renúncia do credor em relação ao previsto no contrato. No entanto, diante do texto expresso da lei, afigura-se desnecessário fazer menção ao instituto, que deve ser esgrimido, em prestígio da boa-fé objetiva, em circunstâncias bem definidas, nas quais se estabelece uma posição jurídica pelo comportamento dos figurantes.

\subsection{Tu Quoque}

O tu quoque (também tu) ocorre quando aquele que infringiu uma regra de conduta pretende postular que se recrimine outrem pelo mesmo comportamento. O sistema jurídico não admite que alguém pretenda exigir que terceiros acatem comento legal ou contratual por ele mesmo desrespeitado (DANTAS JUNIOR, 2008, p. 378). Para Rosenvald (2005, p. 141), quem não cumpre seus deveres também não pode exigir os seus direitos com base na norma violada, sob pena de abuso. 
A noção pode ser compreendida melhor nas máximas turpitudinem suam allegans non auditur (ninguém pode alegar a própria torpeza em seu benefício) ou equity must come with clean hands. Encontra-se positivada em nosso Código, dentre outros exemplos, a proibição de o jovem entre 16 e 18 anos, que dolosamente ocultou sua idade quando inquirido pela outra parte, eximir-se de uma obrigação invocando sua própria incapacidade (art. 180).

No mesmo sentido, dispõe o art. 105 do Código Civil que a incapacidade relativa de uma das partes não pode ser invocada pela outra em benefício próprio, nem aproveita aos cointeressados capazes, salvo se, nesse caso, for indivisível o objeto do direito ou da obrigação comum.

Diante das hipóteses de exercício disfuncional de um direito, concorda-se com Cordeiro (2011, p. 649), quando afirma não ser possível, em termos abstratos, determinar áreas imunes à boa-fé, lembrando que ela é "suceptível de colorir toda a zona de permissibilidade, actuando ou não consoante as circunstâncias" 34 .

Não obstante, é necessário registrar preocupação sobre os limites da investigação do juiz na aferição de quais são os comportamentos consentâneos com a boa-fé diante da expansão dos deveres laterais de conduta e sua crescente complexidade. Vale a advertência de Couto e Silva (2006, p. 38): "impõe-se, entretanto, cautela na aplicação do princípio da boa-fé, pois, do contrário, poderia resultar verdadeira subversão dogmática, aluindo os conceitos fundamentais da relação jurídica, dos direitos e dos deveres". Anote-se, outrossim, que:

o dever que se cumpre, ou se descumpre, é dever para com uma pessoa determinada. As relações que se

${ }_{34}$ Para Cordeiro (2011, p. 649), "impõe-se, assim, à reflexão, um nível instrumental da boa fé: ela reduz a margem de discricionariedade da actuação privada, em função de objectivos externos. [...] A boa fé não contemporiza, pois, com cumprimentos formais; exige, numa atitude metodológica particular perante a realidade jurídica, a concretização material dos escopos visados. Este aspecto relva no domínio dos deveres acessórios, em boa parte destinados a promover a realização material das condutas devidas, sem frustrar o fim do credor e sem agravar a vinculação do devedor". 
estabelecem com essa pessoa são, também, determinadas. A conformidade ou desconformidade do procedimento dos sujeitos da relação com a boa-fé é, por igual, verificável apenas in concreto, examinando-se o fato sobre o qual o princípio incide, e daí induzindo seu significado. (COUTO E SILVA, 2006, p. 37)

Dirigindo-se aos juízes, o referido autor prossegue com suas advertências:

A relevância recentemente dada ao princípio da boa-fé, no campo do direito das obrigações, expressa talvez a principal reação contra as ideias e o sistema do positivismo jurídico, no plano da ciência do direito. Como reação, entretanto, pode ser levado a extremos, ferindo-se, assim, outros valores que o ordenamento jurídico consagra. [...] A aplicação do princípio da boa-fé, tem, porém, função harmonizadora, conciliando o rigorismo lógico-dedutivo da ciência do direito do século passado com a vida e as exigências éticas atuais, abrindo, por assim dizer, no hortus conclusus do sistema do positivismo jurídico, 'janelas para o ético'. Nessa conciliação, a atividade do juiz exerce tarefa de importância. Seu arbítrio, no entanto [...] não é subjetivo, pois que limitado pelos demais princípios jurídicos, os quais, igualmente, têm de aplicar. Nesse mútuo condicionamento de regras, quais serão as relativações ditadas pela boa-fé? A resposta não pode ser dada a priori. (COUTO E SILVA, 2006, p. 37)

Reitere-se que não se pretende afastar a possibilidade de controle do conteúdo convencional do negócio jurídico pelo magistrado, pois, como bem adverte Prata (1982, p. 56), "a integração não se encontra dependente da existência de lacunas"35; no entanto, é preciso preservar

35 Segundo a citada autora, "a utilização dos instrumentos correctivos dos efeitos pretendidos pelas particulares por parte do juiz pode ir desde uma particular capacidade de intervenção na interpretação e integração do regulamento contratual, à qualificação de uma situação não expressamente prevista pela lei como ilícita, com o consequente declarar sua invalidade e/ou da existência de um direito a indemnização, ou ainda à possibilidade de alterar o contrato ou, pura e simplesmente, resolvê-lo, verificadas dadas circunstâncias. Das três formas que a intervenção judicial pode assumir, a segunda enunciada reconduz-se ao estudo da identificação teórica dos deveres impostos pela ordem pública, bons costumes e boa fé e das consequências jurídicas da ofensa destes" (PRATA, 1982, p. 56). 
o ajuste contratual quando as cláusulas negociais tiverem sido pactuadas de modo válido e regular - observando-se os deveres decorrentes da boa-fé -, desde que não tenha ocorrido alguma alteração significativa nas circunstâncias definidoras a base do negócio e que tenham a capacidade de interferir no equilíbrio negocial preexistente ${ }^{36}$.

Sobre o tema, vale transcrever a decisão do Superior Tribunal de Justiça que concluiu pela inexistência de violação ao dever geral de boa-fé na compra e venda de safra futura a preço certo, em face das peculiaridades do caso concreto.

DIREITO CIVILEAGRÁRIO. COMPRAE VENDADE SAFRA FUTURA A PREÇO CERTO. ALTERAÇÃO DO VALOR DO PRODUTONOMERCADO.CIRCUNSTÂNCIAPREVISÍVEL. ONEROSIDADE EXCESSIVA. INEXISTÊNCIA. VIOLAÇÃO AOS PRINCÍPIOS DA FUNÇÃO SOCIAL DO CONTRATO, BOA-FÉ OBJETIVA E PROBIDADE. INEXISTÊNCIA. A compra e venda de safra futura, a preço certo, obriga as partes se o fato que alterou o valor do produto agrícola não era imprevisível. Na hipótese afigura-se impossível admitir onerosidade excessiva, inclusive porque a alta do dólar em virtude das eleições presidenciais e da iminência de guerra no Oriente Médio - motivos alegados pelo recorrido para sustentar a ocorrência de acontecimento extraordinário - porque são circunstâncias previsíveis, que podem ser levadas em consideração quando se contrata a venda para entrega futura com preço certo. $\mathrm{O}$ fato do comprador

36 "CIVIL E PROCESSUAL CIVIL. DECISÃO CONCESSIVA DE LIMINAR. RECURSO ESPECIAL RETIDO. ART. 542, § $3^{\circ}$, DO CPC. NÃO-INCIDÊNCIA. ROMPIMENTO CONTRATUAL IMOTIVADO. LEI N. ${ }^{\circ} 6.729 / 79$ - 'LEI FERRARI'. BOA-FÉ OBJETIVA. LIBERDADE CONTRATUAL. MANUTENÇÃO FORÇADA DO CONTRATO.IMPOSSIBILIDADE. [...] 2. O princípio da boa-fé objetiva impõe aos contratantes um padrão de conduta pautada na probidade, 'assim na conclusão do contrato, como em sua execução', dispõe o art. 422 do Código Civil de 2002. Nessa linha, muito embora o comportamento exigido dos contratantes deva pautar-se pela boa-fé contratual, tal diretriz não obriga as partes a manterem-se vinculadas contratualmente ad aeternum, mas indica que as controvérsias nas quais o direito ao rompimento contratual tenha sido exercido de forma desmotivada, imoderada ou anormal, resolvem-se, se for o caso, em perdas e danos. [...]" (REsp. 966.163/RS, Rel. Ministro Luis Felipe Salomão, Quarta Turma, julgado em 26/10/2010, DJe 4/11/2010). 
obter maior margem de lucro na revenda, decorrente da majoração do preço do produto no mercado após a celebração do negócio, não indica a existência de má-fé, improbidade ou tentativa de desvio da função social do contrato. A função social infligida ao contrato não pode desconsiderar seu papel primário e natural, que é o econômico. Ao assegurar a venda de sua colheita futura, é de se esperar que o produtor inclua nos seus cálculos todos os custos em que poderá incorrer, tanto os decorrentes dos próprios termos do contrato, como aqueles derivados das condições da lavoura. A boa-fé objetiva se apresenta como uma exigência de lealdade, modelo objetivo de conduta, arquétipo social pelo qual impõe o poderdever de que cada pessoa ajuste a própria conduta a esse modelo, agindo como agiria uma pessoa honesta, escorreita e leal. Não tendo o comprador agido de forma contrária a tais princípios, não há como inquinar seu comportamento de violador da boa-fé objetiva. Recurso especial conhecido e provido. (REsp. 803.481/GO, Rel. Ministra Nancy Andrighi, Terceira Turma, julgado em 28/6/2007, DJ 1/8/2007, p. 462). (Grifou-se)

O fundamento último da possibilidade de intervenção no compromisso negocial dos contratantes repousa na constatação de que parte do conteúdo obrigacional de uma relação jurídica negocial não depende da vontade dos envolvidos, estando fora de seu controle (DANTAS JUNIOR, 2008, p. 204-207).

Embora a enumeração dos deveres gerais de conduta não possa ser considerada taxativa, deve-se atentar para a advertência de Pablo Stolze Gagliano e Rodolfo Pamplona Filho (2005, p. 77), os quais sustentam que, na investigação da causa genética dos deveres anexos, não se poderia prescindir dos fatos materiais de que são originados, como as negociações preliminares. No mesmo sentido, Cordeiro (2011, p. 646) afirma que:

a boa-fé apenas normatiza certos factos que, estes sim, são fonte: mantenha-se o paralelo com a fenomenologia 
da eficácia negocial: a sua fonte reside não na norma que mande respeitar os negócios, mas no próprio negócio em $\mathrm{si}^{37}$.

\section{Conclusão}

Não é possível, em termos abstratos, determinar áreas imunes à boa-fé. Entretanto, há que se analisar com cautela os limites da investigação do juiz na aferição de quais são os comportamentos que são consentâneos a ela diante da expansão dos deveres gerais de conduta e de sua crescente complexidade.

A boa-fé está relacionada aos fatores socioculturais de um determinado lugar e momento. Seu conceito não pode ser encontrado na análise do texto legal, mas na decisão judicial que aprecia como deve ocorrer sua aplicação, levando em consideração as circunstâncias do caso concreto e exigindo, para sua compreensão, mais da análise da atividade judicial do que da análise de textos doutrinários.

Não é tarefa fácil substituir uma aparelhagem jurídica tradicional. A solução, sem perder de vista a perspectiva histórica e social da evolução da matéria, não apresenta apenas uma via. O debate em torno da utilidade e oportunidade da readequação das categorias objeto desse trabalho deve prosseguir mediante ponderação de princípios e valores nas relações entre particulares, buscando eficiência funcional a um sistema plural e complexo, em prol da coerência, da complementariedade e da coordenação das categorias.

37 Prosseguindo com o raciocínio, o autor sustenta que "o Direito obriga, então, a que, nessas circunstâncias, as pessoas não se desviem dos propósitos que, em ponderação social, emerjam da situação em que se achem colocadas: não devem assumir comportamentos que a contradigam - deveres de lealdade - nem calar ou falsear a atividade intelectual externa que informa a convivência humana - deveres de informação. Embora as estruturas e teleologia básicas sejam as mesmas, advinha-se a presença de concretizações diversas, consoante os fatos que lhes dêem origem" (CORDEIRO, 2011, p. 646). 


\section{Referências}

AGUIAR JÚNIOR, Ruy Rosado de. Extinção dos contratos por incumprimento do devedor. Rio de Janeiro: Aide, 2004.

ALBUQUERQUE, Fabíola Santos. A tutela da confiança e seus reflexos na responsabilidade civil. In: VIEGAS, Frederico (Org.). Direito civil contemporâneo. Brasília, DF, Obcursos, 2009. p. 61-74.

CAVALIERI FILHO, Sérgio. Programa de responsabilidade civil. 9. ed. São Paulo: Atlas, 2010.

COMTE-SPONVILLE, André. Pequeno tratado das grandes virtudes. Tradução de Eduardo Brandão. São Paulo: Martins Fontes, 1999. Disponível em: <http://www.pfilosofia.pop.com.br/03_filosofia/ 03_03_ pequeno_tratado_das_ grandes_virtudes/ pequeno_tratado_das grandes_virtudes.htm, p. 105 e seguintes>. Acesso em: 12 dez. 2011.

CORDEIRO, António Manuel da Rocha Menezes. Da boa-fé no direito civil. Coimbra: Almedina, 2011.

COUTO E SILVA, Clóvis V. A obrigação como processo. Rio de Janeiro: FGV, 2006.

DANTAS JUNIOR, Aldemiro Rezende. Teoria dos atos próprios no princípio da boa-fé. Curitiba: Juruá, 2008.

DEMOGUE, René. Traité des obligations em général. Paris: Librairie Arthur Rosseau, 1923.

DIAS, José Aguiar. Da responsabilidade civil. 11. ed. Rio de Janeiro: Renovar, 2006.

DIREITO, Carlos Alberto Menezes; CAVALIERI FILHO, Sérgio. Comentários ao novo código civil: da responsabilidade civil: das preferências e privilégios creditórios (arts. 927 a 965). Rio de Janeiro: Forense, 2004. v. XIII.

DUARTE, Ronnie Preuss. A cláusula geral da boa-fé no novo código civil brasileiro. In: DELGADO, Mário Luiz; ALVES, Jones Figueiredo. Novo código civil: questões controvertidas. São Paulo: Método, 2004. v. 2. p. 399-433. 
FRADERA, Véra Maria Jacob de. A boa-fé objetiva, uma noção presente no conceito alemão, brasileiro e japonês de contrato. Revista Brasileira de Direito Comparado, Rio de Janeiro, n. 24, p. 127-157, jan./jun. 2003. GAGLIANO, Pablo Stolze; PAMPLONA FILHO, Rodolfo. Novo curso de direito civil: contratos. São Paulo: Saraiva, 2005. v. IV.

GOMES, José Jairo. Responsabilidade civil e eticidade. Belo Horizonte: Del Rey, 2005.

HIRONAKA, Giselda Maria Fernandes Novaes (Org.). Ensaios sobre responsabilidade civil na pós-modernidade. Porto Alegre: Magister, 2007.

ITURRASPE, Jorge Mosset; PIEDECASAS, Miguel A. Responsabilidad contractual. Buenos Aires: Rubinzal-Culzoni, 2007.

JALUZOT, Béatrice. La bonne foi dans les contrats: étude comparative de droit français, allemand et japonais. Paris: Dalloz, 2001.

LEWICKI, Bruno. Panorama da boa-fé objetiva. In: TEPEDINO, Gustavo (Coord.). Problemas de direito civil-constitucional. Rio de Janeiro: Renovar, 2000. p. 55-75.

LÔBO, Paulo Luiz Netto. Teoria geral das obrigações. São Paulo: Saraiva, 2005.

. Direito civil: contratos. São Paulo: Saraiva, 2011a.

. Obrigações. São Paulo: Saraiva, 2011b.

LORENZETTI, Ricardo Luis. Fundamentos do direito privado. São Paulo: Revista dos Tribunais, 1998.

. La oferta como apariencia y la aceptación basada en la confianza. Revista de Direito do Consumidor, São Paulo, n. 35, p. 5-20, jul./set. 2000.

MARQUES, Cláudia Lima. Contratos no código de defesa do consumidor: o novo regime das relações contratuais. 6. ed. São Paulo: Revista dos Tribunais, 2011. 
MARTINS-COSTA, Judith. A boa-fé no direito privado: sistema e tópica no processo obrigacional. São Paulo: Revista dos Tribunais, 1999.

MAYO, Jorge Alberto; PREVOT, Juan Manuel. Responsabilidad contractual. Buenos Aires: La Ley, 2007.

MAZEAUD, Denis. Solidarisme contractuel et réalisation du contrat. In: GRYBAUM, Luc; NICOD, Marc. Le solidarisme contratuel. Paris: Economica, 2004. p. 57-71.

MELLO, Heloisa Carpena Vieira de. A boa-fé como parâmetro da abusividade no direito contratual. In: TEPEDINO, Gustavo (Coord.). Problemas de direito civil-constitucional. Rio de Janeiro: Renovar, 2000. p. 307-324.

MELLO, Marcos Bernardes de. Teoria do fato jurídico: plano de eficácia. São Paulo: Saraiva, 2003.

MESSINEO, Francesco. Derecho civil y comercial. Buenos Aires: EJEA, 1971. v. II.

MORELLO, Augusto M. Indemnización del daño contractual. Buenos Airres: Abeledo-Perrot, 2003.

MOTA, Maurício; KLOH, Gustavo. Transformações contemporâneas do direito das obrigações. Rio de Janeiro: Elsevier, 2011.

NALIN, Paulo. Do contrato: conceito pós-moderno. Curitiba: Juruá, 2001.

NANNI, Giovanni Ettore. Abuso de direito. In: LOTUFO, Renan; NANNI, Giovanni Ettore (Coord.). Teoria geral do direito civil. São Paulo: Atlas, 2008. p. 738-772.

NEGREIROS, Teresa. Fundamentos para uma interpretação constitucional do princípio da boa-fé. Rio de Janeiro: Renovar, 1998.

NERY, Rosa Maria de Andrade (Coord.). Função do direito privado no atual momento histórico. São Paulo: Revista dos Tribunais, 2006. NONATO, Orozimbo. Reparação do dano causado por pessoa privada 
de discernimento. Revista Forense Comemorativa 100 Anos: Direito Civil, Rio de Janeiro, t. III, p. 83-93, 2007.

NORONHA, Fernando. Direito das obrigações. 3. ed. São Paulo: Saraiva, 2010.

PINTO, Paulo Mota. Interesse contratual negativo e interesse contratual positivo. Coimbra: Coimbra Ed., 2008. v. 1.

PINTO, Cristiano Vieira Sobral. Direito civil sistematizado. Rio de Janeiro: Forense, 2011.

PONTES DE MIRANDA, Francisco Cavalcanti. Tratado de direito privado. São Paulo: Revista dos Tribunais, 1958. v. XXV.

POTHIER, Robert Joseph. Tratado das obrigações. Campinas, SP: Servanda, 2002.

PRATA, Ana. A tutela constitucional da autonomia privada. Coimbra: Almedina, 1982.

RÉMY, Philippe. La gênese du solidarisme. In: GRYBAUM, Luc; NICOD, Marc. Le solidarisme contratuel. Paris: Economica, 2004. p. 3-13.

RIBEIRO, Joaquim de Sousa. Direito dos contratos:estudos. Coimbra: Coimbra Ed., 2007.

ROPPO, Enzo. O contrato. Coimbra: Almedina, 2009.

ROSENVALD, Nelson. Dignidade humana e boa-fé no código civil. São Paulo: Saraiva, 2005.

SANSEVERINO, Paulo de Tarso Vieira. Princípio da reparação integral. São Paulo: Saraiva, 2010.

SCHREIBER, Anderson. A proibição de comportamento contraditório: tutela da confiança e venire contra factum proprium. Rio de Janeiro: Renovar, 2005.

TEPEDINO, Gustavo. Código civil interpretado: parte geral e obrigações. Rio de Janeiro: Renovar, 2004. v.1. 
USTÁRROZ, Daniel. Responsabilidade contratual. São Paulo: Revista dos Tribunais, 2007.

VINEY, Geneviève; JOURDAIN, Patrice. Traité de droit civil: les effets de la responsabilité. Paris: EJA, 1989.

Recebido em: 11/04/13

Aprovado em: 09/05/13 